\title{
PERLINDUNGAN HUKUM BAGI KONSUMEN AKIBAT PRODUK MAKANAN YANG TIDAK MEMENUHI STANDAR MUTU MENURUT UNDANG-UNDANG REPUBLIK INDONESIA NOMOR 8 TAHUN 1999
}

\author{
Oleh \\ Maria Alberta Liza Quintarti \\ Fakultas Hukum Prodi Ilmu Hukum Universitas Flores \\ Email : lizaquintarti63@gmail.com
}

\begin{abstract}
Abstrak
Peredaran barang dan jasa saat ini tidak lagi dapat dibatasi hanya dalam suatu lingkungan negara tertentu saja, tetati telah menembus batas-batas negara, perbedaan sosial, budaya, ras, agama, dan ideologi. Disamping itu, globalisasi perdagangan dan informatika telah memperluas ruang gerak arus transaksi barang dan jasa yang ditawarkan. Kondisi yang demikian pada satu pihak akan barang dan jasa yang diinginkan dapat terpenuhi serta semakin terbuka lebar kebebasan untuk memilih aneka jenis dan kualitas barang dan jasa sesuai dengan keinginan dan kemampuan konsumen. Namun di sisi lain, keadaan tersebut juga berpotensi menimbulkan permasalahan atau kerugian bagi konsumen. Undang-undang No 8 Tahun 1999 memberikan batasan bagi pelaku usaha dan konsumen, juga memberikan secara khusus tugas dan langsung mengenai perlindungan konsumen, seperti yang tercantum di dalam pasal 45 Undang-Undang tersebut di atas. Dilihat dari segi perdata atau aspek perdata, apabila barabg atau jasa yang dikonsumsinya menimbulkan kerusakan, pencemaran dapat mengajukan gugatan kepada pelaku usaha. Gugatan tersebut dapat diajukan atas dasar perbuatan melawan hukum yang diatur dan tercantum dalam pasal 1365 KUHPerdata. Dalam UUPK pelanggaranpelanggaranyang dilakukan pelaku usaha juga diancam dengan pidana baik berupa pidana penjara, denda, maupun pidana tambahan dalam Pasal 62 UUPK.
\end{abstract}

\section{Kata Kunci : Perlindungan Hukum, Konsumen, Produk Makanan \& Pelaku Usaha}

\section{PENDAHULUAN}

Undang - Undang tentang perlindungan konsumen mengacu pada filosofi pembangunan nasional bahwa pembangunan nasional termasuk pembangunan hukum yang memberikan perlindungan terhadap konsumen adalah dalam rangka membangun manusia Indonesia seutuhnya yang berlandaskan pada falsafah ketenegaraan Republik Indonesia, Yaitu dasar Negara Pancasila dan konsitusi negara yaitu Undang-Undang Dasar 1945.

Mutu pangan menurut Undang-Undang Republik Indonesia Nomor 7 Tahun 1996 tentang Pangan Pasal 1 angka (13) adalah nilai yang ditentukan atas dasar kriteria keamanan pangan, kandungan gizi dan standar perdagangan terhadap bahan makanan dan minuman. Saat ini makanan yang beredar di pasaran, tidak sedikit mengandung zat yang dapat membahayakan tubuh manusia seperti zat pewarna tekstil, pemanis buatan, formalin, boraks dan bahan berbahaya lainnya. Dinas terkait seperti Badan Pengawasan Obat dan Makanan, Dinas Kesehatan, Dinas Perindustrian dan Perdagangan sudah rutin melakukan sidak, pengawasan, dan pembinaan terhadap industri rumah tangga. Namun makanan dengan zat yang berbahaya tetap saja ditemukan. Permasalahan tersebut timbul disebabkan antara lain karena baik konsumen maupun pelaku usaha pada umumnya belum memiliki pengetahuan dan kesadaran akan hak dan kewajiban masing-masing. Disamping itu, hukum yang mengatur tentang perlindungan konsumenpun belum dibuat secara komprehensif dan integral.

Di Indonesia masalah perlindungan konsumen itu sendiri baru mulai terdengar 
tagun 1970, ini terutama ditandai dengan lahirnya Yayasan Lembaga Konsumen (YLK). Secara histori pada awalnya yayasan ini berkaitan dengan rasa mawas diri terhadap promosi untuk memperlancar barang-barang dalam negeri. Karena desakan dari masyarakat untuk melindunginya, maka puncaknya lahirlah Yayasan Lembaga Konsumen dengan moto yaitu melindungi konsumen, menjaga martabat konsumen dan membantu pemerintah. Lalu dengan diikuti pada dengan lahirnya UndangUndang Nomor 8 Tahun 1999 tentang Perlindungan Konsumen.

Agar seluruh proses pengolahan makanan tersebut memenuhi persyaratan keamanan, mutu dan gizi pangan, maka perlu diwujudkan suatu sistem pembinaan dan pengawasan yang efektif dibidang keamanan, mutu dan gizi pangan. Pembinaan terhadap produsen mengandung makna mendorong pelaku usaha supaya bertindak sesuai aturan yang berlaku, baik aturan yang diharuskan undang-undang, kebiasaan maupun kepatutan.

Perlindungan terhadap konsumen dipandang secara materiil maupun formal makin terasa sangat penting, mengingat semakin lajunya ilmu pengetahuan dan teknologi yang merupakan motor penggerak bagi produktifitas dan efisiensi pelaku usaha atas barang dan/atau jasa yang dihasilkannya. Dalam rangka mengejar dan mencapai kedua hal tersebut akhirnya baik langsung maupun tidak langsung perlu adanya upaya-upaya untuk memberikan perlindungan yang memadai terhadap kepentingan konsumen. Dengan adanya Undang-Undang Republik Indonesia Nomor 8 Tahun 1999 tentang Perlindungan Konsumen diharapkan upaya perlindungan konsumen di Indonesia bisa lebih ditingkatkan sehingga konsumen kedudukannya tidak selalu di posisi lemah dan pelaku usaha juga dapat lebih meningkatkan kualitas produk yang ditawarkan kepada konsumen.

\section{LANDASAN TEORI}

Undang-Undang Nomor 8 Tahun 1999 memberikan batasan bagi pelaku usaha dan konsumen, juga memberikan secara khusus, tegas dan langsung mengenai perlindungan konsumen, seperti yang tercantum di dalam pasal 45 Undang-Undang tentang penyelesaian sengketa, yaitu :

1. Setiap konsumen yang dirugikan dapat menggugat pelaku usaha melalui lembaga yang bertugas menyelesaikan sengketa antara konsumen dan pelaku usaha atau melalui peradilan yang berada di lingkungan peradilan umum

2. Penyelesaian sengketa konsumen dapat ditempuh melalui pengadilan atau di luar pengadilan berdasarkan pilihan sukarela para pihak yang bersangkutan

3. Penyelesaian sengketa di luar pengadilan sebagaimana dimaksud pada ayat (2) tidak menghilangkan tanggung jawab pidana sebagaimana diatur dalam Undang-Undang

4. Apabila telah dipilih upaya penyelesaiansengketa konsumen ditempuh apabila upaya tersebut dinyatakan tidak berhasil oleh salah satu pihak atau oleh para pihak yang bersengketa.

Jadi perlindungan konsumen di sini adalah segala upaya yang menjamin adanya kepastian hukum untuk memberi perlindungan kepada konsumen, dan pada pasal 45 di atas mengatur mengenai penyelesaian sengketa.

Pengertian pelaku usaha seperti tercantum dalam pasal 1 butir 3 UndangUndang Nomor 8 Tahun 1999, menyatakan : "Pelaku usaha adalah setiap perseorangan atau badan usaha baik yang berbentuk badan hukum maupun bukan badan hukum yang didirikan dan berkedudukan atau melakukan kegiatan dalam wilayah hukum Negara Republik Indonesia baik sendiri maupun bersama-sama melalui perjanjian penyelenggaraan kegiatan usaha dalam berbagai bidang ekonomi". 
Selain pengertian pelaku usaha dalam undang-undang juga dijelaskan pengertian konsumen. Dalam peraturan perundangundangan di Indonesia, istilah "konsumen" sebagai definisi yuridis formal ditemukan pada undang-undang nomor 8 tahun 1999 pasal 1 butir 2, menyatakan :

"Konsumen adalah setiap orang pemakai barang dan/atau jasa yang tersedia dalam masyarakat, baik bagi kepentingan diri sendiri, kreluarga, orang lain maupun mahkluk hidup lain dan tidak untuk diperdagangkan”.

Dalam pasal 1 angka 5 Undang-Undang Nomor 7 Tahun 1996 tentang pangan disebutkan, "produksi pangan adalah kegiatan atau proses menghasilkan, menyiapkan, mengelola, membuat, mengawetkan, mengemas, mengemas kembali dan atau mengubah bentuk pangan". Makanan hasil produksi ini biasanya merupakan makanan olahan yang dalam pasal 1 angka 2 UndangUndang Pangan disebut sebagai "Makanan atau minuman hasil proses dengan cara atau metode tertentu dengan atau tanpa bahan tambahan.

\section{METODE PENELITIAN}

Adapun jenis penelitian yang digunakan dalam mengkaji permasalahan tersebut yaitu penelitian normatif yaitu dengan mengkaji peraturan perundang- undangan yang berlaku. Sumber bahan hukumyang digunakan berupa bahan hukum primer, bahan hukum sekunder dan bahan hukum tersier. Teknik pengumpulan bahan hukum yang digunakan adalah mengadakan studi pencatatan dokumen yang berkaitan dengan permasalahan dan bahan hukum dengan menginterpretasikan dengan menafsirkan dan mengkaji peraturan perundang-undangan kemudian dituangkan dalam karya ilmiah dengan mengkaitkan permasalahan yang dibahas.Setelah bahan hukum terkumpul, lalu diolah dan dianalisa dengan mempergunakan metode kualitatif. Setelah melalui proses pengolahan dan analisis, kemudian bahan hukum tersebut disajikan secara deskriptif analisis.

\section{HASIL DAN PEMBAHASAN}

a) Tanggung Jawab Pelaku Usaha Apabila Terjadi Kerugian Terhadap Produk Makanan Yang Dipasarkan Bagi Konsumen.

Dalam Undang-Undang Republik Indonesia Nomor 8 Tahun 1999 tentang Perlindungan Konsumen tampak bahwa itikad baik lebih ditekankan pada pelaku usaha, termasuk pelaku usaha industri rumah tangga karena meliputi semua tahapan dalam melakukan kegiatan usahanya, sehingga dapat diartikan bahwa kewajiban pelaku usaha untuk beritikad baik dimulai sejak barang dirancang atau diproduksi sampai pada tahap purna penjualan, sebaliknya konsumen hanya diwajibkan beritikad baik dalam melakukan transaksi pembelian barang dan/atau jasa. Hal ini tentu saja disebabkan oleh kemungkinan terjadinya kerugian bagi konsumen dimulai sejak barang dirancang atau diproduksi oleh produsen atau pelaku usaha, sedangkan bagi konsumen, kemungkinan untuk dapat merugikan produsen mulai pada saat melakukan transaksi dengan produsen. ${ }^{5}$

Berkaitan dengan produksi makanan dan minuman industri rumah tangga yang dengan mudah diperoleh di pasaran, tidak tertutup kemungkinan beredarnya makanan maupun minuman yang tidak memenuhi syarat kesehatan yaitu : aman, bermutu dan bergizi. Setiap orang yang memproduksi pangan yang diedarkan perlu dibebani tanggung jawab, terutama apabila pangan yang diproduksinya menyebabkan, baik kerugian pada kesehatan manusia maupun kematian orang yang mengkonsumsi pangan tersebut.

Produsen atau pelaku usaha bertanggung jawab mutlak atas kerugian yang diderita konsumen, baik berupa gangguan kesehatan atau kematian yang disebabkan oleh mengkonsumsi produk pangan yang beracun atau berbahaya. Pasal 41 ayat (1) UndangUndang Republik Indonesia Nomor 7 Tahun 1996 tentang Pangan menegaskan bahwa 
harus ada pihak yang bertanggung jawab atas keamanan pangan (produk), jika ternyata menimbulkan kerugian kepada konsumen. Dengan kata lain, memberi pertanggungjawaban adalah kewajiban produsen. Dasar pertanggungjawaban produsen dapat juga dilihat dalam Pasal 41 ayat (4) Undang-Undang Republik Indonesia Nomor 7 Tahun 1996 yang mengatur bahwa: "Selain ketentuan sebagaimana dimaksud pada ayat (3), dalam hal badan usaha dan atau orang dalam badan usaha dapat membuktikan bahwa hal tersebut bukan diakibatkan kesalahannya, maka badan usaha dan atau orang perorangan dalam badan usaha tidak wajib mengganti kerugian".

b) Sanksi Hukum terhadap Pelaku UsahaApabila Konsumen Dirugikan Akibat Mengkonsumsi Makanan yang Mengandung Zat Berbahaya

Pasal 8 angka (1) huruf (a), angka (2) dan angka (3) Undang-Undang Republik Indonesia Nomor 8 Tahun 1999 tentang Perlindungan Konsumen menetapkan sejumlah larangan kepada pelaku usaha yaitu : pelaku usaha dilarang memproduksi dan memperdagangkan barang yang dapat berupa sediaan farmasi dan pangan yang rusak, cacat atau tercemar, dan tidak sesuai dengan standar yang ditentukan undang-undang.

Pemerintah dalam melakukan pengawasan terhadap produk makanan yang berbedar diberi wewenang untuk mengambil tindakan administratif, sesuai dengan yang tercantum dalam Pasal 54 angka (2) UndangUndang Republik Indonesia Nomor 7 Tahun 1996 tentang Pangan, tindakan administratif yang dimaksud berupa : Peringatan secara tertulis; Larangan mengedarkan untuk sementara waktu dan/atau perintah untuk menarik pangan dari peredaran apabila terhadap resiko tercemarnya pangan atau pangan tidak aman bagi kesehatan manusia; Pemusnahan pangan jika terbukti membahayakan kesehatan da jiwa manusia;
Penghentian produk untuk sementara waktu; Pengenaan denda paling tinggi Rp.50.000.000,00 (lima puluh juta rupiah); dan Pencabutan izin produksi atau izin usaha.

\section{PENUTUP}

\section{Kesimpulan}

Tanggung jawab pelaku usaha apabila terjadi kerugian terhadap produk makanan yang dipasarkan bagi konsumen adalah bertanggung jawab mutlak atas kerugian yang diderita konsumen, baik berupa gangguan kesehatan atau kematian yang disebabkan karena mengkonsumsi produk makanan maupun minuman yang beracun atau berbahaya. Penggantian kerugian yang dimaksud dapat berupa perawatan kesehatan dan pemberian santunan kepada konsumen yang dirugikan atau ahli warisnya atau kesepakatan dari para pihak itu sendiri.

Sanksi hukum terhadap pelaku usaha makanan dan minuman berskala industri rumah tangga yang terbukti melakukan pelanggaran dengan menggunakan zat-zat berbahaya dalam proses produksi dilakukan dalam bentuk penarikan produk makanan maupun minuman, pemberhentian produksi untuk sementara waktu sampai masalah terkait diatasi dan penarikan nomor pangan industri rumah tangga, pemusnahan makanan maupun minuman tersebut jika terbukti membahayakan kesehatan dan jiwa manusia, dan pencabutan izin produksi atau izin usaha.

\section{DAFTAR PUSTAKA}

[1] Janus Sidabalok, 2006, Hukum Perlindungan Konsumen di Indonesia, Cet. I, Citra Aditya Bakti, Bandung.

[2] Husni Syawali dan Neni Imaniyanti, 2000, Hukum Perlindungan Konsumen, Bandung,Mandar Maju.

[3] Sunaryati Hartono, 1994, Penelitian Hukum di Indonesia pada Akhir Abad ke20, Alumni, Bandung. 
[4] Amirudin dan Zainal Asikin, 2003, Pengantar Metode Penelitian Hukum, PT. Raja Grafindo Persada, Jakarta.

[5] Ahmadi Miru dan Sutarman Yodo, 2004, Hukum Perlindungan Konsumen, Rajawali Pers, Jakarta

[6] Peraturan Perundang-Undangan

[7] Undang-Undang Republik Indonesia Nomor 8 Tahun 1999 tentang Perlindungan Konsumen, Lembaran Negara Republik Indonesia Tahun 1999 Nomor 3821.

[8] Undang-Undang Republik Indonesia Nomor 7 Tahun 1996 tentang Pangan, Lembaran Negara Republik Indonesia Tahun 1996 Nomor 3656. 
HALAMAN INI SENGAJA DIKOSONGKAN 